\title{
A Research by Design Strategy for Climate Adaptation Solutions: Implementation in the Low-Density, High Flood Risk Context of the Lake District, UK
}

\author{
Ifigenia Psarra $^{1,2, *(\mathbb{C})}$, Özlem Altınkaya Genel ${ }^{2,3}$ (-) and Alex van Spyk ${ }^{2}$ \\ 1 Academy of Architecture, Institute of Future Environments, Hanze University Groningen, \\ 9747 AS Groningen, The Netherlands \\ 2 Research Center for Built Environment Noorder Ruimte, Hanze University Groningen, 9747 AS Groningen, \\ The Netherlands; ozlemaltinkaya@gmail.com (Ö.A.G.); a.p.d.van.spyk@pl.hanze.nl (A.v.S.) \\ 3 Faculty of Architecture and Design, Özyeğin University, Istanbul 34794, Turkey \\ * Correspondence: i.psarra@pl.hanze.nl
}

Citation: Psarra, I.; Altınkaya Genel, Ö.; van Spyk, A. A Research by Design Strategy for Climate Adaptation Solutions: Implementation in the Low-Density, High Flood Risk Context of the Lake District, UK. Sustainability 2021, 13, 11847. https://doi.org/ $10.3390 /$ su132111847

Academic Editor: Leire Garmendia

Received: 17 September 2021

Accepted: 18 October 2021

Published: 27 October 2021

Publisher's Note: MDPI stays neutral with regard to jurisdictional claims in published maps and institutional affiliations.

Copyright: (C) 2021 by the authors. Licensee MDPI, Basel, Switzerland. This article is an open access article distributed under the terms and conditions of the Creative Commons Attribution (CC BY) license (https:// creativecommons.org/licenses/by/ $4.0 /)$.

\begin{abstract}
The purpose of this paper is to propose a research by design strategy, focusing on the generation of innovative climate adaptation solutions by utilizing the Design Thinking Process. The proposed strategy has been developed and tested in a research and design studio, which took place in 2020 at a Master of Architecture degree program in the Netherlands. The studios focused on the sparsely populated, high flood risk region of the Lake District, UK. The Lake District faces urgent climate change challenges that demand effective solutions. On the other hand, the area is a UNESCO heritage site, characterized by massive tourism and tending towards museumification (sic). Three indicative design research projects were selected to illustrate the proposed research by design strategy. The results reveal that this strategy facilitates the iterative research by design process and hence offers a systematic approach to convert the threats of climate change into opportunities by unraveling the potentials of the study area. The findings lay the groundwork for more systematic studies on research by design as an effective strategy for climate change adaptation design. Beyond the local case, the results contribute to the critical theories on climate adaptation design and research by design methodologies.
\end{abstract}

Keywords: climate adaptation; research by design; design thinking process; the Lake District; lowdensity; high flood risk; uncertainty; spatial planning

\section{Introduction}

An important body of research work focuses on the policy dimensions, risk assessment, and social dimensions of climate adaptation [1-4], with a strong emphasis on technological advances [5]. Less attention has been paid, however, to the spatial planning and design challenges of the phenomenon. The uncertainty and wicked problems [6] precipitated by climate change demand radical spatial solutions for resilient landscapes. Thus, urban planners and designers need to embrace the dynamic conditions and changing demands in the planning practice. To achieve this, comprehensive and transformative design methods are needed, allowing the planners and designers to approach climate change adaptation as a complex spatial design challenge $[7,8]$. This paper focuses on the development of a research by design strategy for climate adaptation solutions.

Spatial planning based on research by design is a growing field and in its application to a diverse set of urban and rural contexts, it is also used to tackle the uncertainty of environmental problems [9-12]. While these studies show great diversity in comprehending research by design, they share a commonality in their non-linear, yet integrated, research approach.

There is an important body of literature on research by design that focuses on descriptions of the process followed by practitioners of researcher designer. For instance, 
the pre-design and post-design phases [13], the iterative nature of the process, and the divergence and convergence phases [14]. Additionally, the experiences and design outcomes of studios in a university setting where research by design has been used [13-17] have contributed to the better understanding and cultivation of desirable future scenarios. However, research by design still lacks clear guidelines that define its applicability to complex urban design and planning problems related to climate adaptation [10,15].

The main research question of this study is how the research by design process can be adapted and systematically utilized to generate climate adaptation solutions. How can the iterative loops of research by design be filled in with specific directions on how to approach a study area, analyze it, and formulate climate adaptation ideas, concepts, projects, and designs?

To this end, this study formulates a four-step strategy that is based on the iterative context of the research by design process, in the sense that each of the four steps corresponds to an iterative loop. This four-step strategy aims to convert the threats of climate change into opportunities and to offer a compass to designers who want to apply research by design to arrive at radical and effective climate adaptation solutions. Each step of this strategy entails specific analytical questions, design approaches, and criteria which can serve as anchoring points and that can offer guidance to the researcher designer.

In particular, the suggested strategy consists of the following:

1. Approaching the study area as a complex adaptive system [18] in which the previous states of equilibrium are also investigated;

2. Developing and using the worst-case climate change scenario as the point of departure in both conceptualization and external dialogue;

3. Considering the spatial-systemic and the mental-social sphere of the study area by identifying, safeguarding, and enhancing the relevant ecosystem services [19] in the proposed climate adaptation solution;

4. Considering a gradual, phased sequence of implementation of the design solution.

From January to July 2020, research and design studios were organized within the Master of Architecture degree program and in collaboration with the Spatial Transformations lectureship at the Hanze University of Applied Sciences, Groningen, the Netherlands, jointly with the Master of Architecture program at Queen's University Belfast, Northern Ireland. Designing for resilience to the effects of climate change was the collective theme. The research aim was to develop and test a specific research by design strategy, based upon the Design Thinking Process diagram developed by the Future Urban Regions lectureship in the Netherlands [14]. The Lake District, UK was selected as a case study of an ultra-lowdensity region facing significant climate change challenges, whilst also being a UNESCO world-heritage site.

It was found that the implementation of this strategy contributed to the effective use of research by design by the students. It was applied within a wide range of projects focusing on different aspects of climate adaptation challenges in the study area (extreme weather phenomena, heritage, tourism, food production, etc.). It resulted in innovative and creative climate adaptation design proposals. Finally, it enabled the students to embrace uncertainty by converting the threats of climate change into opportunities, and to generate place-based, adaptive, and innovative solutions, which took into account both the physical and the mental sphere of the study area.

The outline of this paper is as follows. First, the context of this study is explained by discussing the challenges imposed by climate adaptation on the planning practice of low-density areas, while a brief description of the study area is provided. Secondly, after describing in brief the research by design methodology used, the proposed fourstep strategy is explained in detail. Thirdly, the three indicative design research projects, originating from the aforementioned research and design studios on climate adaptation, are presented. The way the suggested strategy is reflected in these three examples is discussed in the light of the results and from these the main conclusions are drawn. 


\section{Climate Adaptation as a Spatial Planning Challenge and a Case Study}

\subsection{The Challenge of Climate Change Adaptation Design in Rural Landscapes}

The negative impacts of climate change, arguably the greatest global challenge at this time [20] on urban and rural settlements, include hotter and drier summers, droughts, flooding, rising sea levels and storm surges. These sudden changes and wicked problems point to two primary challenges: first, coping with the aforementioned direct impacts of climate change [21-23] and adapting to the unforeseen future changes; second, tackling the indirect variation anomalies and subtle changes in environmental conditions, such as the disruptions to food production, energy systems and water cycles [24]. Moreover, next to the direct and indirect climate change impacts, additional environmental/climatic hazards, such as the heat island effect, contribute to the complexity of these wicked problems. The complexity of these problems creates uncertainty that abolishes "ultimate solutions" [13].

This climate change-related uncertainty has an influence upon various "components, relationships and interactions" [25] (p. 1986) and demands systemic and comprehensive methodologies. This challenge has been approached from many different angles in the field of spatial planning and decision making [26,27].

Nevertheless, recent studies have demonstrated that climate adaptation strategies still lack a long term transformative approach [28], specifically in terms of spatial interventions [5]. This can ultimately result in conservative approaches which hinder the provision of effective or, if necessary, radical solutions.

Within this framework, the spatial transformation of low-density territories demands long-term transformative approaches in spatial planning and design. In low-density territories, the boundaries between urban and rural fade and the rural characteristics rapidly dismantle [29]. The demise of the rural socio-professional structure, the degradation of traditional rural life, the ever-increasing mobility of individuals, and a networked society interconnected through robust infrastructures are often some of the main characteristics of contemporary low-density territories [30-32]. The massive changes, including new social paradigms, technological advancements, cultural and economic transitions, and the spatial transition from rural to urban demonstrate the dynamism of these landscapes [31,33,34]. This dynamism also facilitates the integration of these territories into "regional, national, or international networks" [35] (p. 15). This integration, however, often transforms lowdensity territories into spaces of touristic consumption [35].

Finally, resilience is also an important challenge imposed by climate adaptation in rural landscapes. Indicatively, Restemeyer [36] discusses the challenges of tackling flooding in urban areas. In flood risk management, resistance and resilience have different connotations. Resistance is associated with keeping water away and preventing flooding via dikes or other flood defenses. Resilience pertains to limiting the consequences of floods and consists of three components: robustness, adaptability, and transformation. Robustness refers to the fight against small-scale floods and limiting damage. This strategy is insufficient for larger threats that require adaptability. Adaptability is identified with relatively controlled flooding. The main principle of adaptability is to learn how to live with floods by designing the landscape in such a way that the water does not damage buildings or infrastructure. The third part of resilience, transformability, interrogates the ability to make a place physically and mentally resilient to flooding. For instance, transformability focuses on the capacity of a village to respond to new events based on novel insights to remain resilient in the future. Transformability requires the knowledge, creativity, and the ability to come up with innovative solutions to deal with new situations.

\subsection{Brief Description of the Study Area}

The study area was the low-density, high flood risk region of the Lake District, in Cumbria, UK, characterized by scenic landscapes [37]. It covers $2362 \mathrm{~km}^{2}$ and has a population of 41,000 residents. It was designated a World Heritage site in 2017, qualifying for the continuity of traditional farming and local industry in a mountain landscape of exceptional beauty. The Lake District has a unique multi-layered landscape that is open to 
different cultural interpretations or functions [38]. For art and literature lovers and escapists, it is the home of Ruskin and the Romantics; for adventure lovers, it is a playground for quad biking, off-roading, etc. This area, which has operated as a cultural landscape for 250 years [39] is currently confronted with museumification [30], expressed in the traditional and conservative approaches of the local society and government. On the other hand, with an economy primarily based on agriculture and tourism [38], the area is strongly affected by globalization and climate change. Globalization triggers mass tourism and global retailers distort the traditional values and ideas of place that characterize the region. Moreover, climate change imposes an urgency for the redefinition of the area's identity and a similar urgency to make it more resilient. These tensions, including countervailing forces such as museumification and globalization, have characterized the contemporary landscape of the Lake District, and this formed the thematic focus for the climate adaptation research and design studios. Thus, the Lake District was considered a suitable case study for these studios because it provided a wide range of overarching problems and climate adaptation challenges, resulting in a great variety of student research design projects. This, subsequently, also offered an appropriate opportunity to test the implementation of the proposed four-step strategy across various projects of different scales and themes across the full spectrum of challenges in this area.

\section{The Research by Design Method and the Suggested Four-Step Strategy \\ 3.1. Research by Design}

The challenges of tackling climate change, and its impact on low-density rural regions, demand not only out-of-the-box solutions, but also an integrated and strategic approach to design for the long-term. The research by design method is such an approach that helps us to comprehend spatial planning and design across different scales. The research by design method situates "design" in the core of the probing process to explore and identify opportunities for improvement [40,41]. Design as a reflexive practice [42] heavily relies on critical evaluation and reflection [43]. This is achieved via spatial explorations, such as sketching, mapping, material analysis, modeling, and design artefacts [40,43]. The nonlinear process of design, based on these operational tools, creates a constant flux between the problem and possible solutions [44]. Therefore, the constructed dichotomy [15,43] between research and design is removed via this mutual interaction.

Tackling uncertainty and complexity is an integral part of this dynamic and exploratory process [45]. In this way, research by design supports the investigation of wicked problems, and thus the exploration of future prospects, based on imaginative research [14].

While research by design is approached differently by scholars and practitioners [41], convergence, divergence, iteration, and feedback loops remain the fundamental aspects, facilitating the complex decision-making processes. The Design Thinking Process (DTP) diagram developed by the Future Urban Regions research group demonstrates the various stages of research by design including strategy, idea, concept, project, design, product, and monitoring (Figure 1).

Each stage is a consolidation point composed of a divergence and convergence phase. While the divergence phase leads to a diverse set of research questions and possible solutions based on analysis, the convergence phase is utilized for synthesis. Specifically, as can be seen in Figure 1, inform and combine are the two main steps of the divergence phase, while choose and implement the two main steps of the convergence phase. The reduced bandwidth in the diagram demonstrates that research gradually becomes more concentrated and focused [14]. Throughout the whole process, the act of design leads to new knowledge and possible future scenarios.

\subsection{Development of a Four-Step Climate Adaptation Strategy Based on Research by Design}

In the field of climate change adaptation design, research by design can be utilized for the much-needed change from the existing paradigm to a new paradigm. This study proposes a four-step strategy embedded in the general framework of research by design. The 
steps of the strategy (corresponding to each of the first four stages of the Design Thinking Process diagram) are: (1) Equilibrium in the past, (2) Worst case scenario, (3) Ecosystem services, and (4) Gradual implementation.

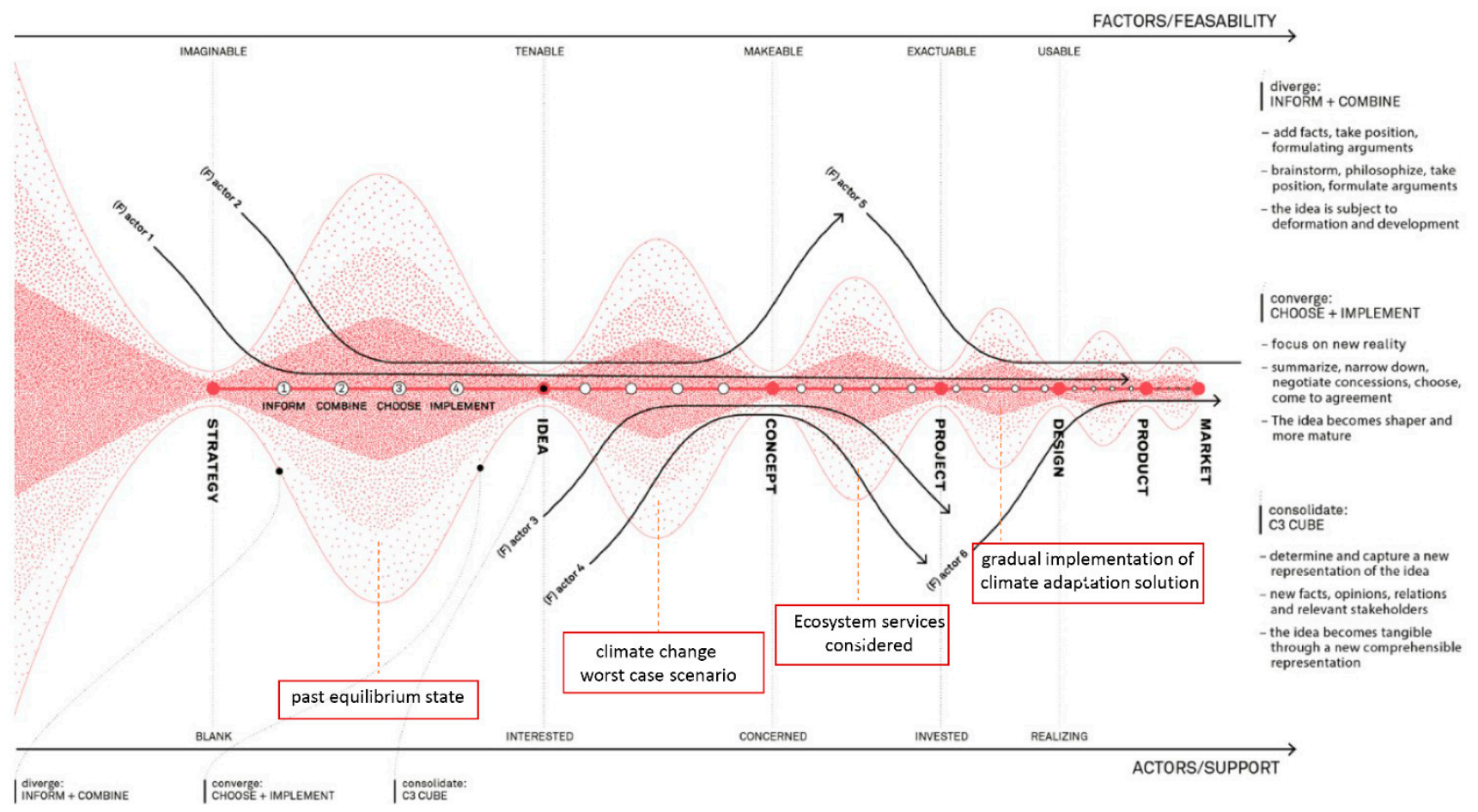

Figure 1. The suggested four-step strategy embedded in the Design Thinking Process Diagram [14] (pp. 128-129). For citations to the four steps see text below and $[7,19,26,27,46-56]$.

\subsubsection{Equilibrium in the Past}

The term "state of equilibrium" as used in this paper refers to the current common meaning, as opposed to the specific definition used in physics. The common meaning originates in ecological discussions of the late 20th century and concerns a broad range of systems and also includes the management of organizations as an example [46,47]. In the context of this paper and the case studies in which it is referenced, the state of equilibrium refers to the conditions of the natural environment (geophysical and ecological) and the resilience of the biomes within it to natural climatic variations. In the case studies presented within this paper, the current condition of the Lake District is assumed to be in an "alternative stable state". This describes the area's reduced ecological carrying capacity and resilience to climatic variations. Notwithstanding this definition of equilibrium in the natural environment, people (human cultural patterns of development and economic activities) are assumed to have largely co-existed within the environmental and climatic restrictions of the region. Within the case study area, the change in these patterns was most evident during and after the Industrial Revolution and the associated building of dams and the excavation of mineral quarries. This article therefore assumes that humans lived more in equilibrium with their environment up until this time, even if the biomes were altered from their previous natural state.

The first step of the proposed strategy is based upon the concept of past equilibrium as described above. This step corresponds with the first iterative loop of the DTP, the idea formulation phase. Specifically:

- Inform: A historical analysis of the study area is of key importance, oriented towards the identification of the main drivers of change (including major sociopolitical events, human interventions within the natural landscape, extreme weather phenomena incidents, etc). A thorough historical analysis that tracks back to moments of significant 
change leads to the identification of the most recent point of time when the natural and man-made systems were in balance $[7,48,49]$. Key stakeholders can play an important role in this process by offering their insights into this analysis;

- Combine: Then, a flow analysis reveals the spatial dynamics within the system (s), not with the purpose of reproducing the past state, but to identify the underpinning conditions, values, or concepts that enabled this equilibrium state;

- Choose: Based on that analysis, the particular characteristics of the study area, which can play a key role in the formulation of a new vision for the future, are selected;

- Implement: In this way, a new idea, based upon specific criteria about the climate's adaptive potential and a resilient future of the study area is formulated (Figure 2).

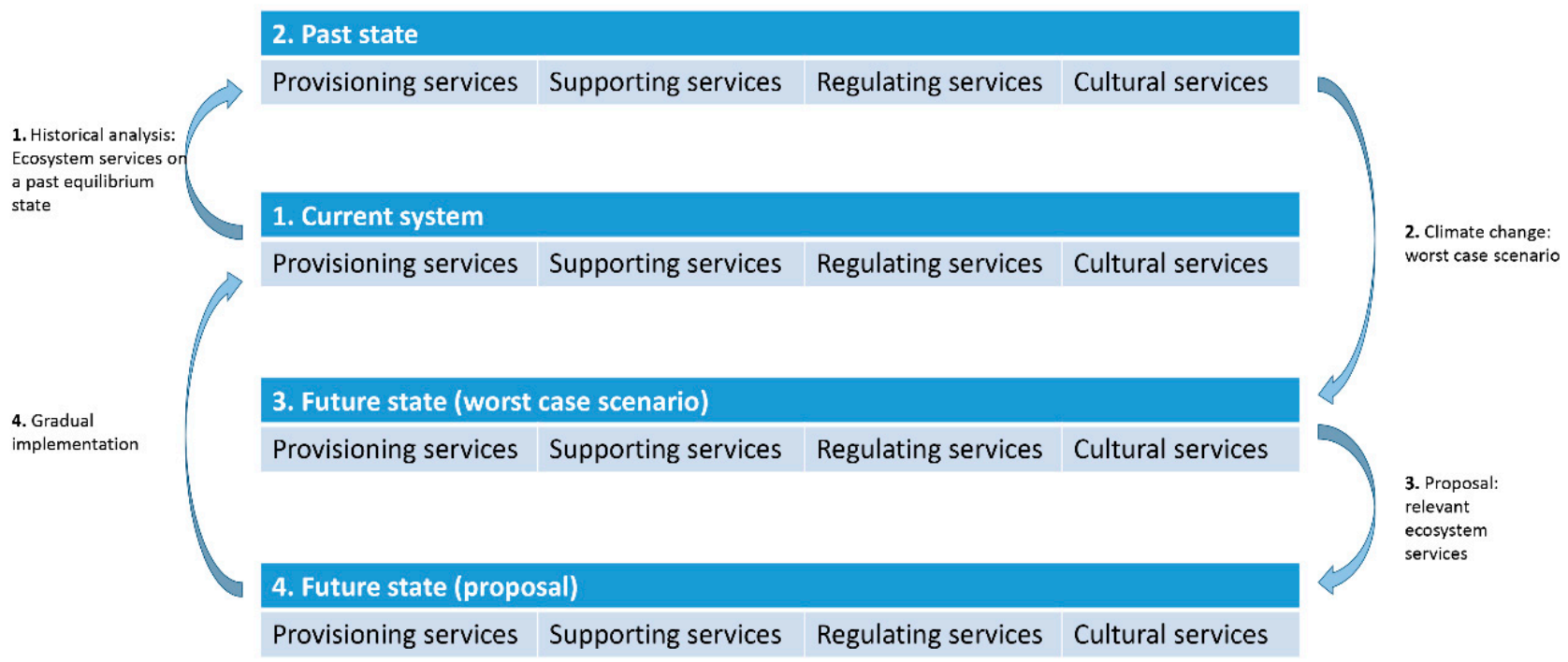

Figure 2. Diagram depicting the main steps of the suggested research by design strategy.

\subsubsection{Worst Case Scenario}

The second step of the proposed strategy corresponds to the second iterative loop of the Design Thinking Process Diagram, i.e., to the transition from an idea to a concrete concept. Specifically:

- Inform: The major climate change challenges of the study area are addressed, based on relevant data;

- Combine: Several pre-set future scenarios on the impact of climate change in the area are identified [26,27];

- Choose: Based on that, the worst case scenario is developed and visualized [50];

- Implement: The main concept is then constructed upon this basis and the ideas formulated previously. A co-creation process with the relevant stakeholders can be implemented to formulate this concept.

\subsubsection{Ecosystem Services}

The third step of the proposed strategy corresponds to the third iterative loop of the Design Thinking Process Diagram, namely the transition from concept to project. Specifically:

- Inform: A systematic spatial analysis, including geographical and statistical analyses, as well as exploratory fieldwork of the study area, is essential for its spatial exploration. To this end, a spatial categorization based on the ecosystem services approach is proposed. Ecosystem services are defined as the benefits people obtain from ecosystems [19,51,52]. This study focuses on three groups of ecosystem services that relate to the spatial-systemic sphere [53] (namely, provisioning, regulating, and supporting ecosystem services) and one ecosystem service (cultural) linked to the 
mental-social sphere [54]. Specifically, examples of provisioning services are food and water; supporting services refer to soil formation and nutrient cycling; regulating services are related to regulation of floods, drought, land degradation and diseases; while cultural services correspond to recreational, spiritual, religious and other non-material benefits $[55,56]$;

- Combine: An analysis of the relevant ecosystem services enables one to systematically reveal and highlight the local qualities. The combination of ecosystem services identification with the previous steps creates the criteria for a generic framework of alternative future conditions, based on which various alternative scenarios are formulated. Specifically, the first step of the proposed strategy results in a number of qualities, values, and concepts that were used to characterize the study area in previous states when the system was more in balance. These are supposed to serve as a starting point for the new desired (more climate adaptive) situation. Additionally, the outcome of the second step of the proposed strategy is a visualization of the worst-case scenario in terms of climate change for the study area, aiming at revealing possible untapped potential;

- Choose: The preferred scenario is selected and visualized (some ecosystem services can be emphasized to a greater extent than others). Key stakeholders can be directly involved in this process;

- Implement: The process of visualizing the selected scenario and designing its spatial expression by taking into account and safeguarding/enhancing the results of the relevant ecosystem services in the project's development.

\subsubsection{Gradual Implementation}

The last step of the proposed strategy corresponds to the fourth iterative loop of the Design Thinking Process Diagram, the transition from project to design. Specifically:

- Inform: Gradual implementation opportunities and the potential role of relevant stakeholders and other factors are identified;

- Combine: Based on these, a gradual implementation scenario is formulated;

- Choose: The effectiveness and interconnection of the steps required to achieve the scenario are then analyzed;

- Implement: The gradual implementation approach of the project is designed.

\section{Results}

\subsection{Studio Structure}

The research and design studios focused on the low-density, high flood risk region of the Lake District, UK. The main approach of the studios was based on ways to cope with the direct and indirect impacts of climate change in the Lake District (i.e., extreme weather phenomena, flooding). The students paid special attention to the impact of climate change on food, energy, and water. Mapping and explorative spatial design aimed at an analysis of the regional complexity. The studios were evidence-based and supported by a situated learning environment [57]. The regional scale was the point of departure; however, the scale of the student projects varied based on the student preferences and positioning.

The duration of the research studio was eight weeks. The first four were devoted to group work. Each group was assigned a different set of perspectives to study the food, energy, and water systems of the study area (its spatial conditions, socio-economic trends, resource flows, infrastructure, governance, art (scape), flooding and extreme weather phenomena). Students used existing data, GIS sources, and satellite imagery plus historical records to formulate general overviews of probable current and past systemic conditions. During this phase, every team formulated relevant research questions and contributed to collective knowledge about the Lake District. Graphic visualizations, based on the juxtaposition of different layers of information, played a key role in comprehending the spatial systemic properties [14] of the area. This first phase of the research studio resulted in the creation of a comprehensive research atlas consisting of the most important research 
results. As the last step, short individual research projects were conducted during the last four weeks of the research studio. Students were encouraged to scrutinize the research atlas and to formulate their individual projects. These individual research projects constituted the starting point of the student projects during the design studio.

The duration of the design studio was fifteen weeks and the student projects varied in relation to the scale, the area selection within the Lake District, and the particular focus (such as tourism, heritage, food production, flooding challenge, etc.). The students transformed the main research questions of the studio, their acquired knowledge on the theme of climate adaptation, and the spatial systemic properties of the Lake District into a concrete design brief. Then, they applied the proposed four-step research by design strategy (based to a great extent on the analysis they conducted during the research studio).

Summing up, the research and design studios constituted an appropriate opportunity to study the dynamics of the study area and actually became the occasion for the further development of the four-step strategy. It was pedagogically interesting for the students of different years of study to explore their hypotheses through the process of design and by implementing the same four-step strategy (in projects varying in scale, research focus, etc.).

\subsection{Three Indicative Design Research Projects}

Three indicative design research projects, developed in the above-described research and design studios, are selected to illustrate the proposed four-step strategy. In the Lake District, the most urgent problem related to climate change and extreme weather phenomena is the increased frequency and intensity of flooding (Figures 3 and 4). All the design proposals focused on this challenge, with each one emphasizing either the regulation, or the cultural or the provisioning and supporting ecosystem services, respectively (Table 1). Finally, the three research design projects were approached within the framework of [36], and aimed to explore design solutions that would enhance the resilience of the study area, with a particular focus on adaptability and transformation.

Average precipitation Lake district 2010 / 2019

Precipitation

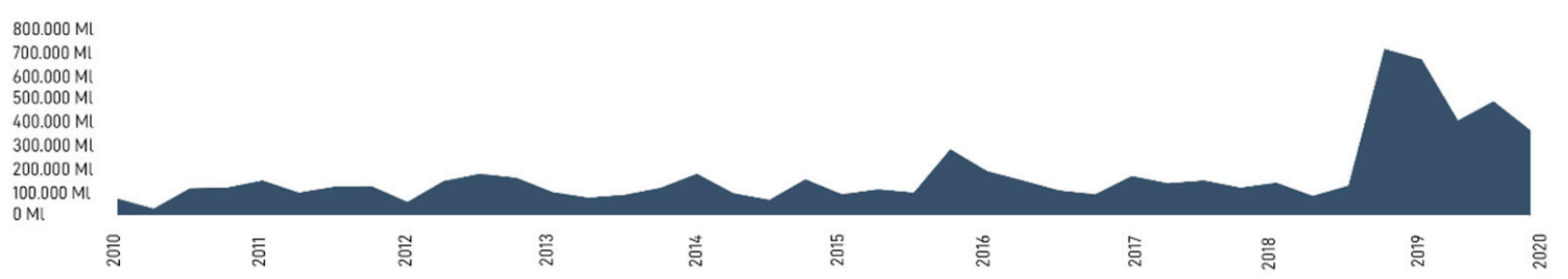

Figure 3. Average precipitation in Lake District in the period between 2010 and 2019.

Table 1. Summary of the three design research projects.

\begin{tabular}{|c|c|c|c|}
\hline & Design Research Project 1 & Design Research Project 2 & Design Research Project 3 \\
\hline name & $\begin{array}{l}\text { Don't fight the water, } \\
\text { embrace it! }\end{array}$ & $\begin{array}{c}\text { Flooding as a tourist } \\
\text { experience }\end{array}$ & Waterdefence trail Kescale \\
\hline $\begin{array}{l}\text { Ecosystem services } \\
\text { (mostly emphasized) }\end{array}$ & Regulating & Cultural & Provisioning and Supporting \\
\hline location in the Lake District & Windermere & Lake Windermere & $\begin{array}{c}\text { Area between Keswick and } \\
\text { Portinscale }\end{array}$ \\
\hline $\begin{array}{l}\text { theme } \\
\text { intervention(s) }\end{array}$ & $\begin{array}{c}\text { floodings, quality of life, } \\
\text { mobility, recreation } \\
\text { dancing streets network, open } \\
\text { water pools, bridge }\end{array}$ & $\begin{array}{l}\text { floodings, tourism, cultural } \\
\text { identity, recreation } \\
\text { a new lake crossing based on } \\
\text { a system of five towers }\end{array}$ & $\begin{array}{l}\text { floodings, food production, } \\
\text { recreation, slow mobility } \\
\text { walking route connecting two } \\
\text { towns, terraces }\end{array}$ \\
\hline
\end{tabular}




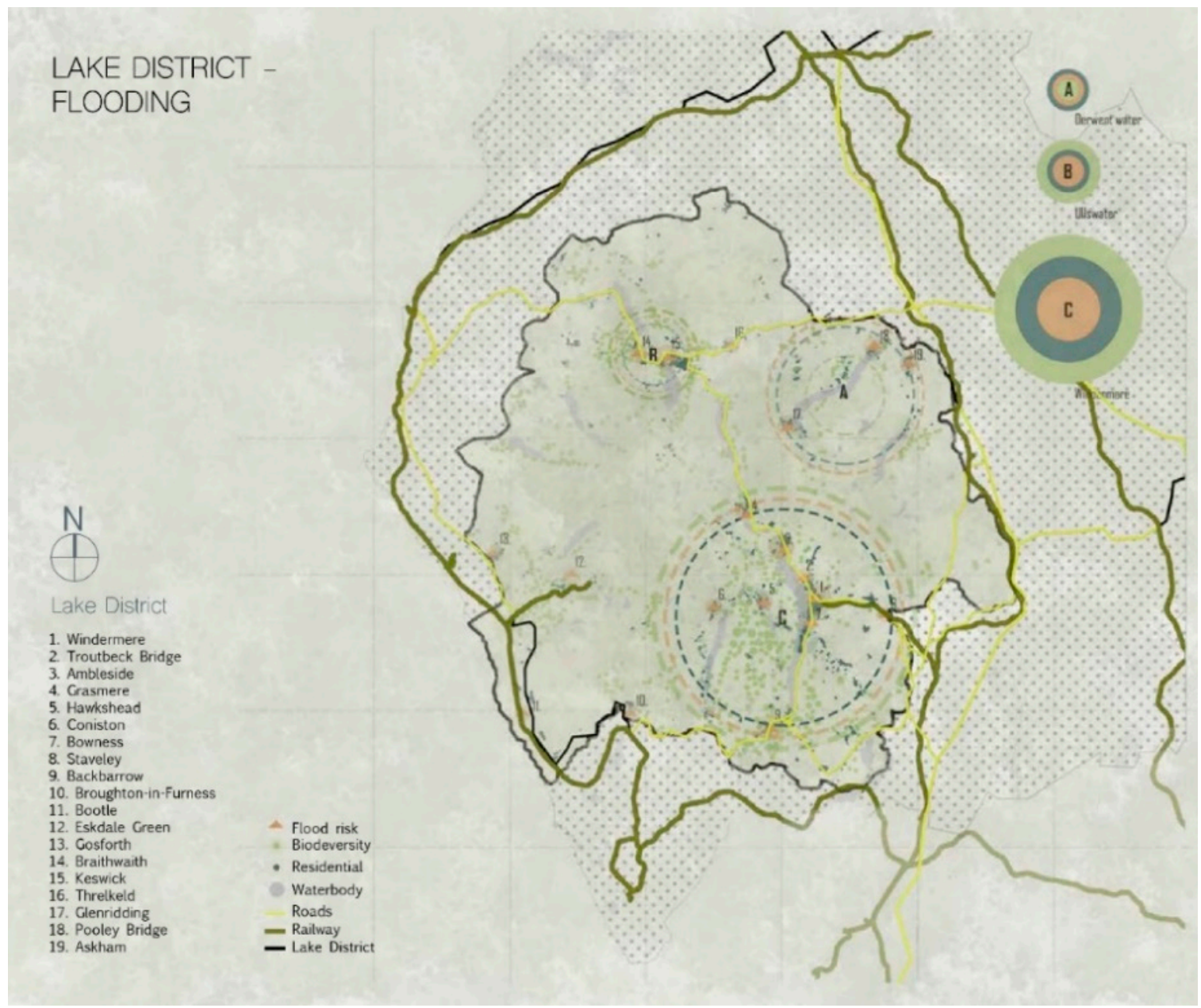

Figure 4. Map of the Lake District, where the three main flood risk zones are depicted.

4.2.1. Design Research Project 1-Don't Fight the Water, Embrace it! The Dancing Streets Concept

This project focuses on the town of Windermere (Figure 5). The frequency of flooding in the Lake District is increasing [58]; however, flooding incidents are unpredictable, and their increasing intensity proves that common actions will no longer be enough to deal with future flooding. This design research project explores ways of using the excess water of floods to create spatial games in Windermere via architecture.
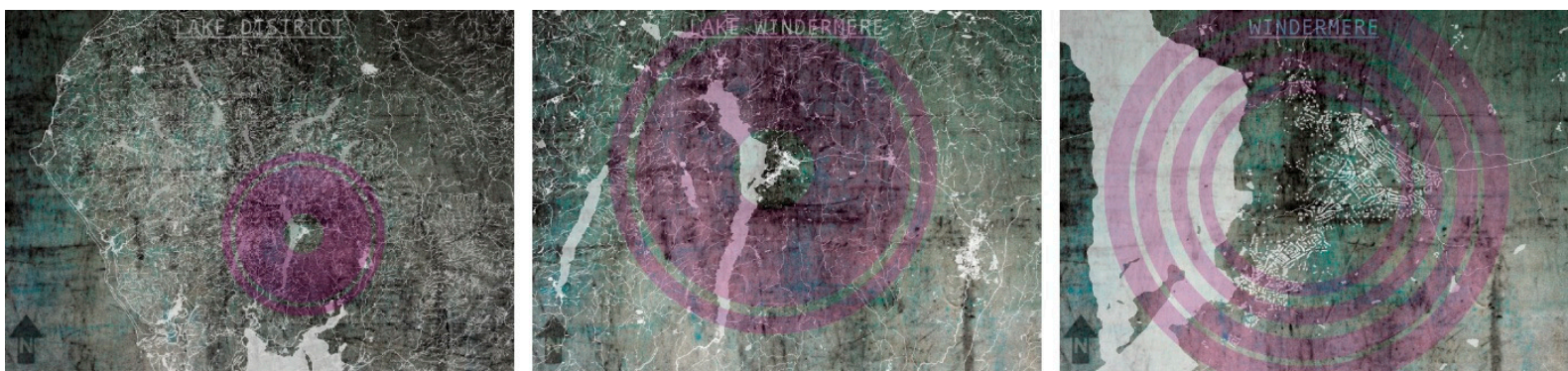

Figure 5. The lake and town of Windermere in the Lake District (diagrams created in the context of the research studio by students). 


\section{Step 1-Past Equilibrium}

In the Lake District, the old equilibrium of forested hills, peat bog, and lakes was lost during the Neolithic period. The new equilibrium of pre-industrial pastoral subsistence defined the local economy of what remained a sparsely populated region up to and including most of the 20th century. An engineered, systematic control of the water began in Victorian times, intensified through the first and second world wars, and then started again in the 1970s during a period of population growth [59]. The 1980s saw the greatest surge in real estate-driven pressure upon the environment-the need for development land, the building of roads, and increased drainage demands and measures against flooding [60]. The situation in the Lake District would be the same for many upland and northern regions in the UK.

\section{Step 2-The Worst-Case Flooding Scenario}

The worst-case flooding scenario was developed by analyzing the current flood risk areas via altitude maps that demonstrated an extreme increase in floods and rainfall in Windermere. As depicted in Figure 6, during heavy rainfall, the narrowing of the Mill Beck River causes flooding in Windermere. According to the worst-case scenario, the illustration of which has been based on maps of previous flooding of the area [61] in combination with the topography of the place, the river may split the town into two disconnected parts.

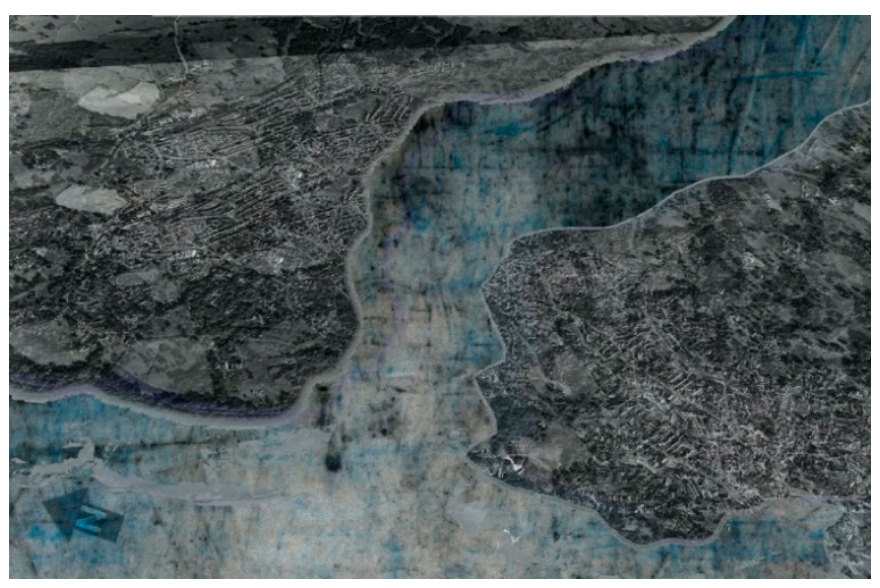

Figure 6. The worst-case flooding scenario for the town of Windermere: the town splits into two parts.

\section{Step 3-Safeguarding/Enhancing Ecosystem Services}

The proposed master plan indicates the proposed interventions to enhance the resilience of Windermere against flooding.

After collecting information and combining different types of water management in the town of Windermere, the student identified two types of water management systems well-suited for this specific location (Figure 7). Firstly, a drainage system is applied under the street, parallel to the river, leading the excess water to the forest. The water is allocated to several water basins via a subsurface pipe system, where the water can be stored during heavy rainfall. Some of these water basins are also used as open pools. Secondly, if the drainage system becomes insufficient for flood prevention, a bridge, connecting the north and south Windermere, will operate (Figure 8). At the top of the columns of the bridge wind turbines are designed to provide power for heating the pools. The excess power will be used by the inhabitants of the village.

Regulating Services: the "dancing streets" concept. The proposal demonstrates a novel way of adapting Windermere's streets to deal more effectively with major flooding events. The dancing streets consist of structural elements which, during a dry spell, are part of the road for traffic or parking, while during flooding events they transform into interactive floating volumes. As can be seen in Figures 9 and 10, the designed vessels act as a form of distributed attenuation system embedded in the road network, a place of the city 
typically used less frequently during a major flooding event. In heavy rainfall, the pipe system under the street is filled with water. The structural containers are pushed up by the water pressure. In this way, the effects of run-off from streets, which typically worsen flooding issues in urban and rural settings, are counteracted. The dancing streets network reminds the residents of the town that they do not need to fear the water (influencing the social-mental sphere of the town).

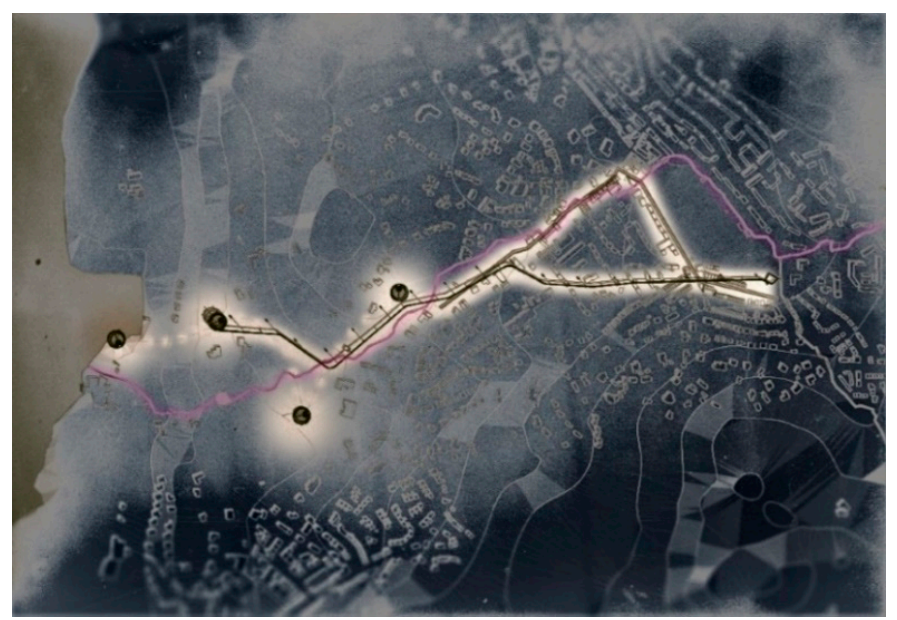

Figure 7. Master plan: flooding-proof Windermere.

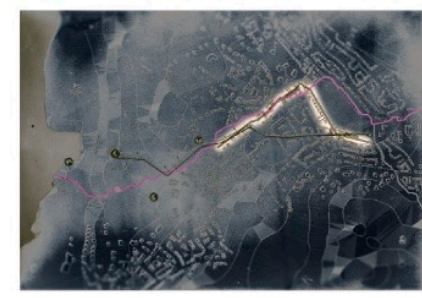

drainage system under the street

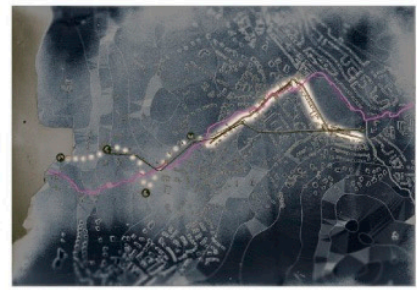

subsurface pipe system in the forest

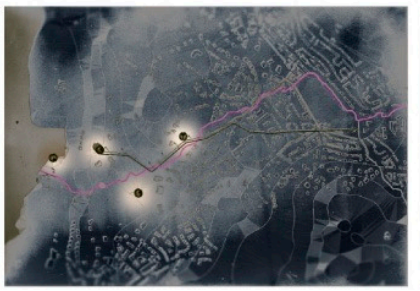

water basins / open water pools

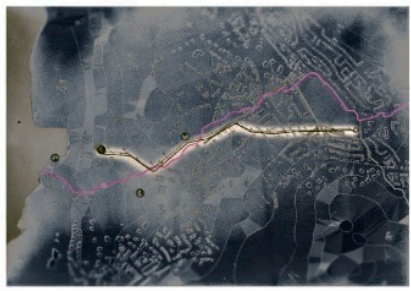
a bridge that connects north and
south windermere.

Figure 8. Explanation of the four types of interventions combined in the master plan.
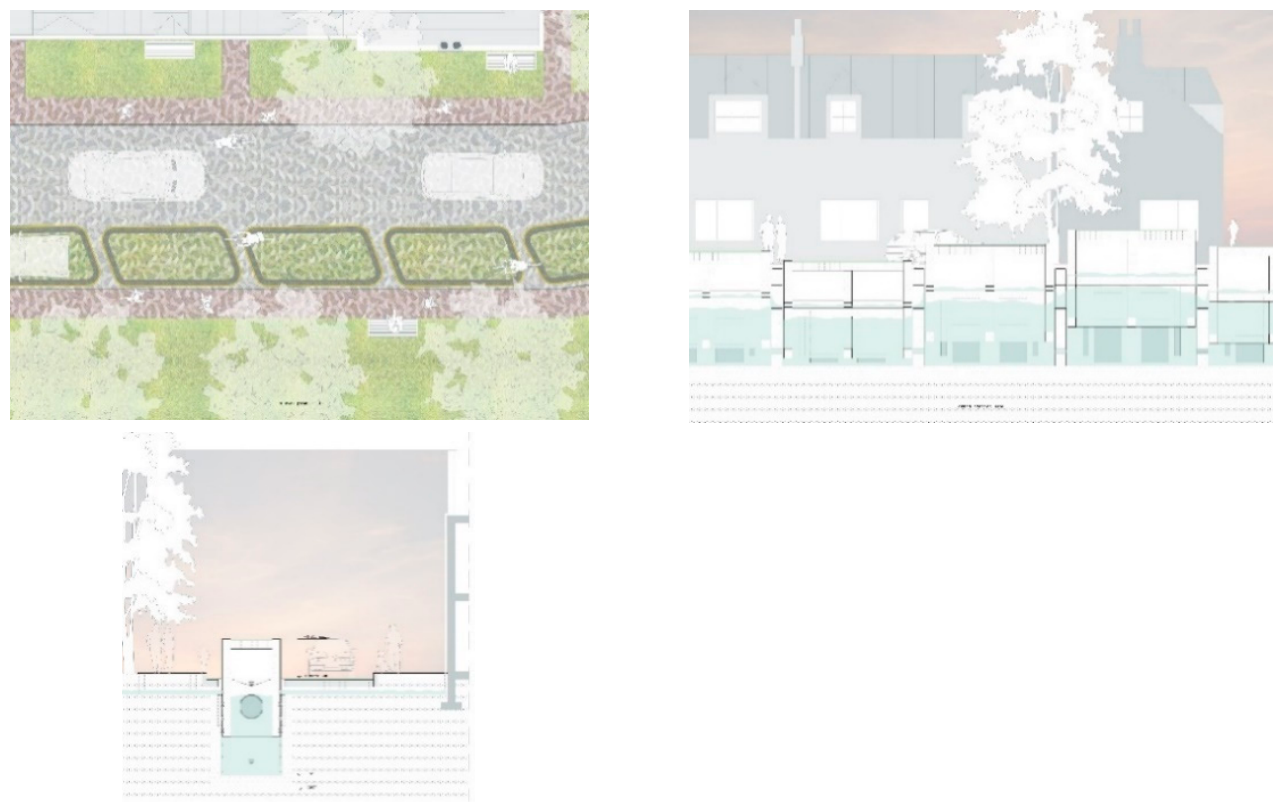

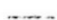

Figure 9. Street plan and two sections depicting the concept of "dancing streets". 

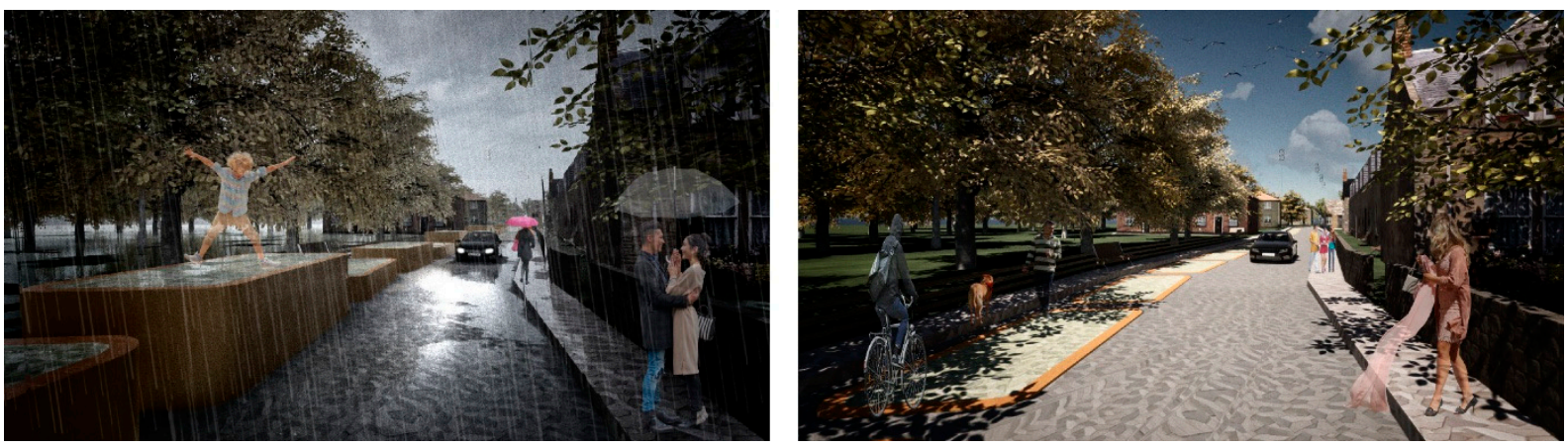

Figure 10. Photorealistic impressions of the "dancing streets" concept. The dancing streets of Windermere on a dry day and during a major flooding event.

Cultural Services: outdoor spas/ water basins in the forest, which are supposed to enhance social interaction (Figure 11). The pools are supplied with water through the subsurface pipe system. Each pool has its own supply and discharge of water. The inlets and outlets are opened or closed automatically in case of heavy rainfall.
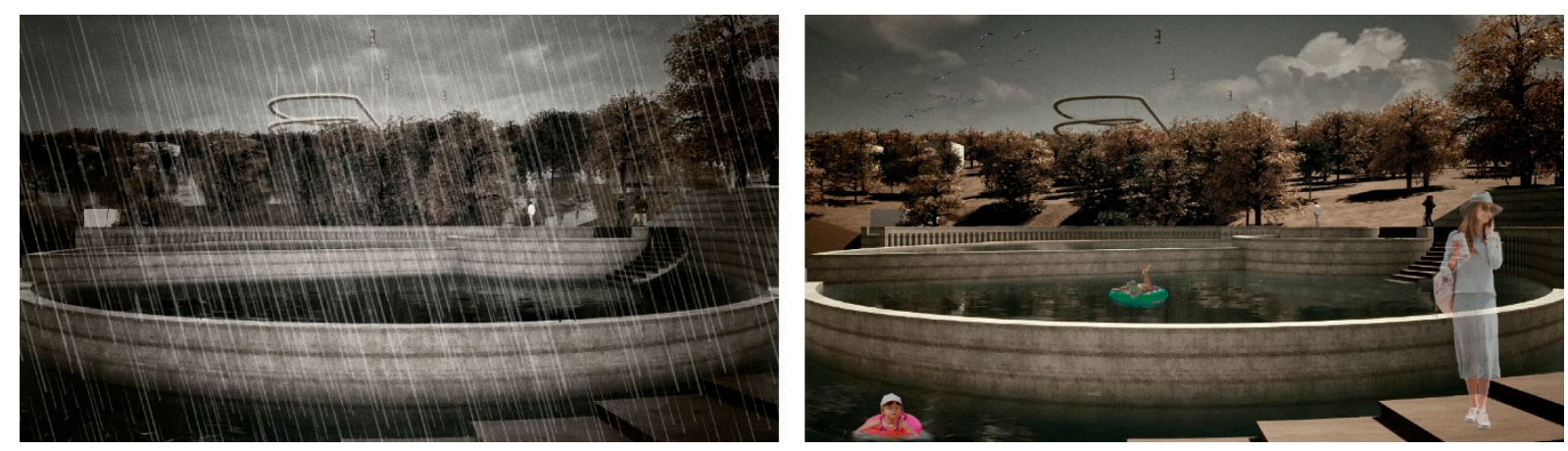

Figure 11. Photorealistic impressions of the pool concept.

Provisioning Services: water basins in the forest (not serving as swimming pools), whose purpose is collecting/harvesting the excess rainwater.

\section{Step 4-Gradual Implementation}

The plan can be implemented incrementally and gradually at a pace that is suited to local inhabitants. It would ultimately create a network of "dancing streets" and open-air pools in and around the town, starting with the areas that are most vulnerable to flooding.

\subsubsection{Design Research Project 2 I Flooding as a Tourist Experience-A New Lake Crossing}

This design research project focuses on Lake Windermere and explores ways of converting the flooding problem into an opportunity to encourage slow tourism in the area. There is a major concern that the increased frequency of heavy rainfalls and flooding in the area will negatively impact tourism. The goal of this study is twofold: to use the floods to save tourism and to improve its quality. Therefore, the study proposes a shift from fast-tourism, which is detrimental to the residents and the environment, to slow-tourism, with a focus on mindfulness (i.e., on how people move through space and become aware of their surroundings and their self-being). To this end, the proposal looks at a new means of crossing the lake, offering tangible experiences with the different water heights of the lake throughout the year.

Step 1-Past Equilibrium

The urge to flee the city because of its daily obstacles has not changed since the arrival of tourism in the Lake District. However, people and their needs have changed. Yoga 
and mindfulness holidays in a natural environment are becoming more and more popular and the attention on mental health is increasing. Despite the need for peace and space for reflection, however, "fast tourism" still dominates the Lake District.

\section{Step 2-The Worst-Case Flooding Scenario}

The aforementioned worst-case flooding scenario for the town of Windermere was also used as a starting point for this proposal (Figure 12).

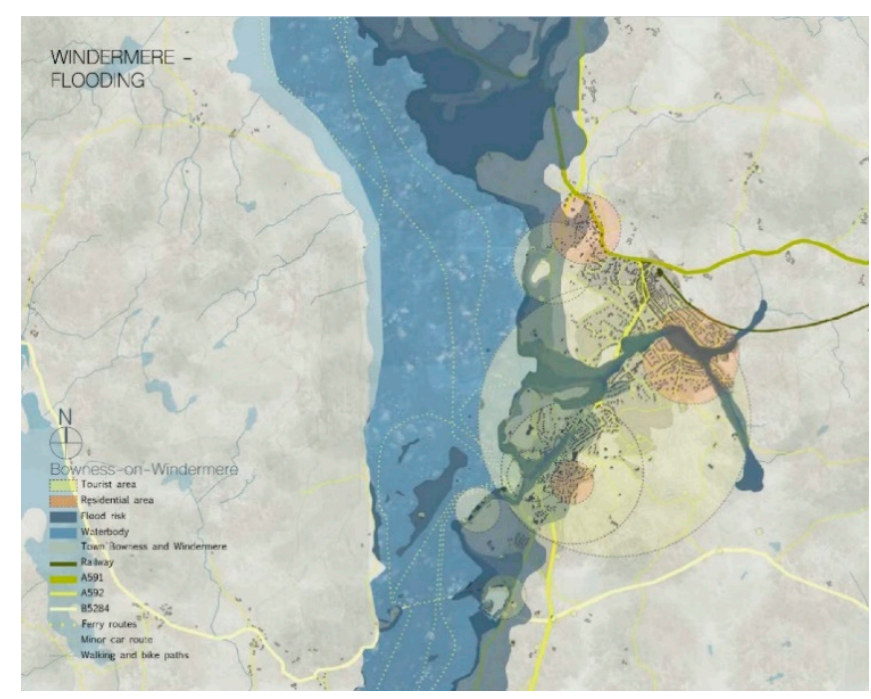

Figure 12. Map of the lake and town of Windermere, indicating the worst-case flooding scenario.

Step 3-Safeguarding/Enhancing Ecosystem Services

Regulating Services: The five towers concept includes a new crossing for Lake Windermere (Figure 13).

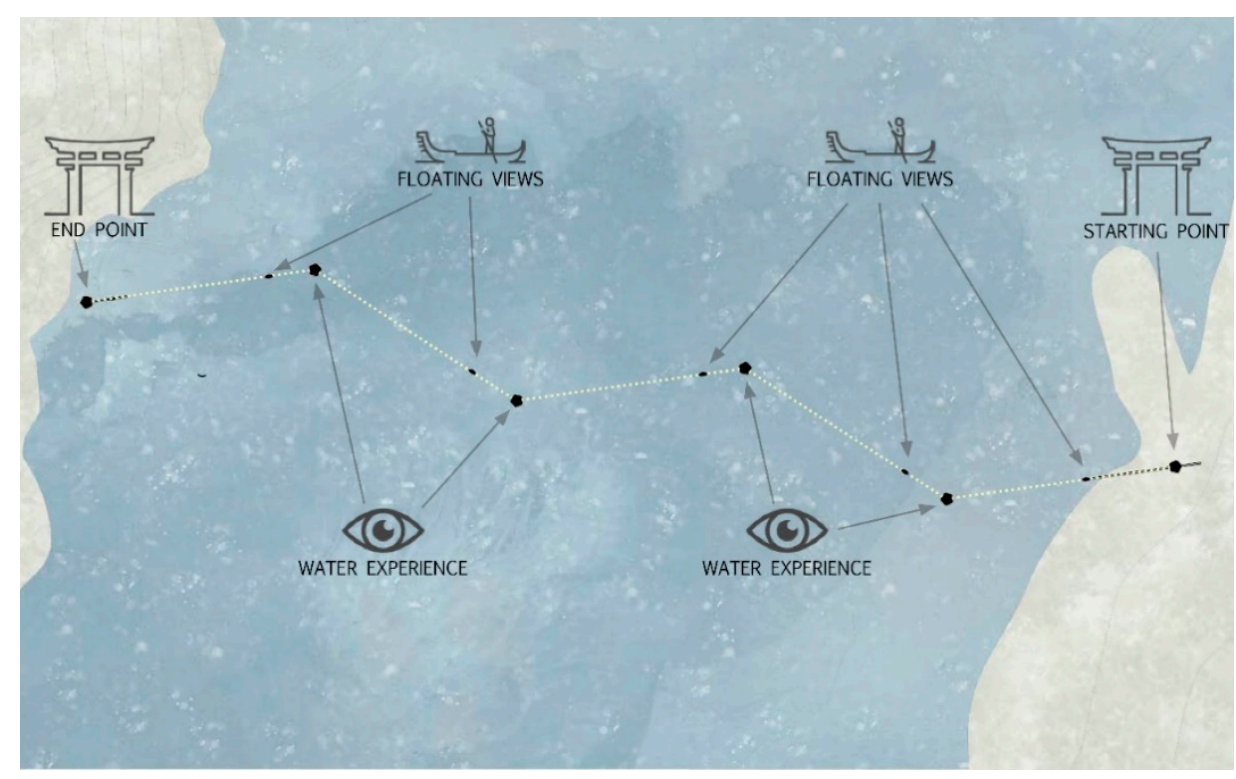

Figure 13. The proposed new crossing and the three mindfulness elements.

The towers construct a network in the lake. Visitors can disembark from their boat and walk up each tower to discover the different dimensions of the Lake District landscape from the water (Figure 14). 


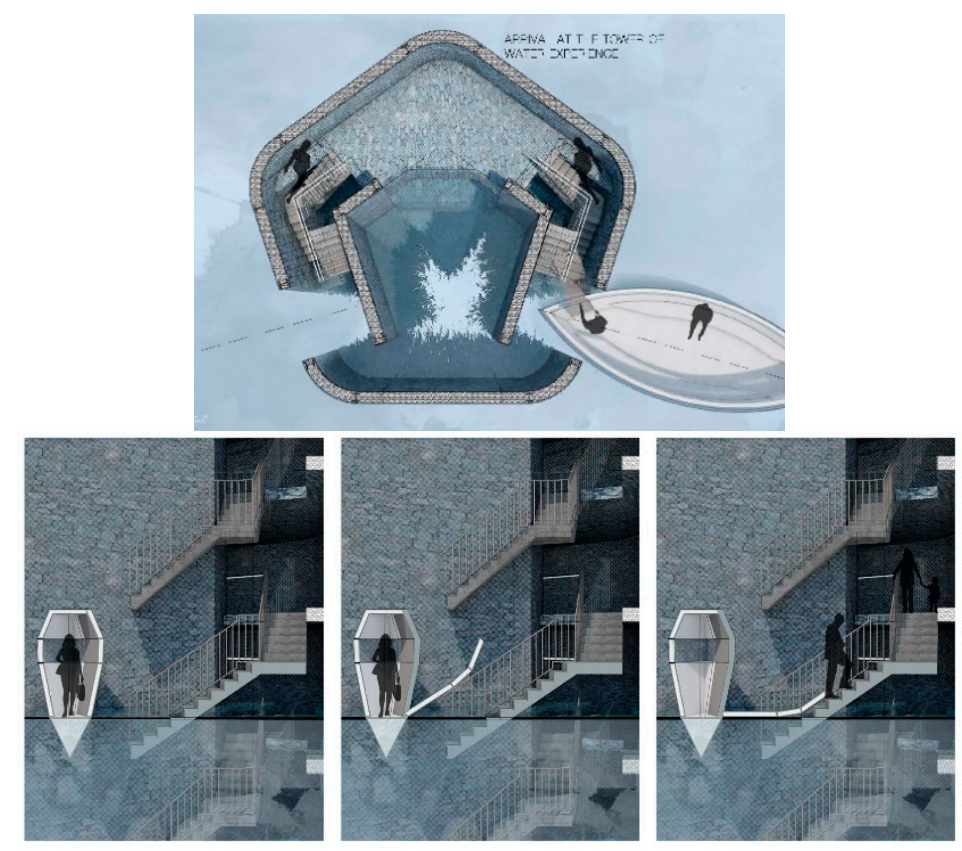

Figure 14. Arrival at a tower.

The varying water levels into the towers throughout the year depend on the seasonality and the (extreme) weather phenomena, which are experienced by the tourist when crossing the lake. The materials of the various towers demonstrate former water heights that changed over the years (Figure 15).
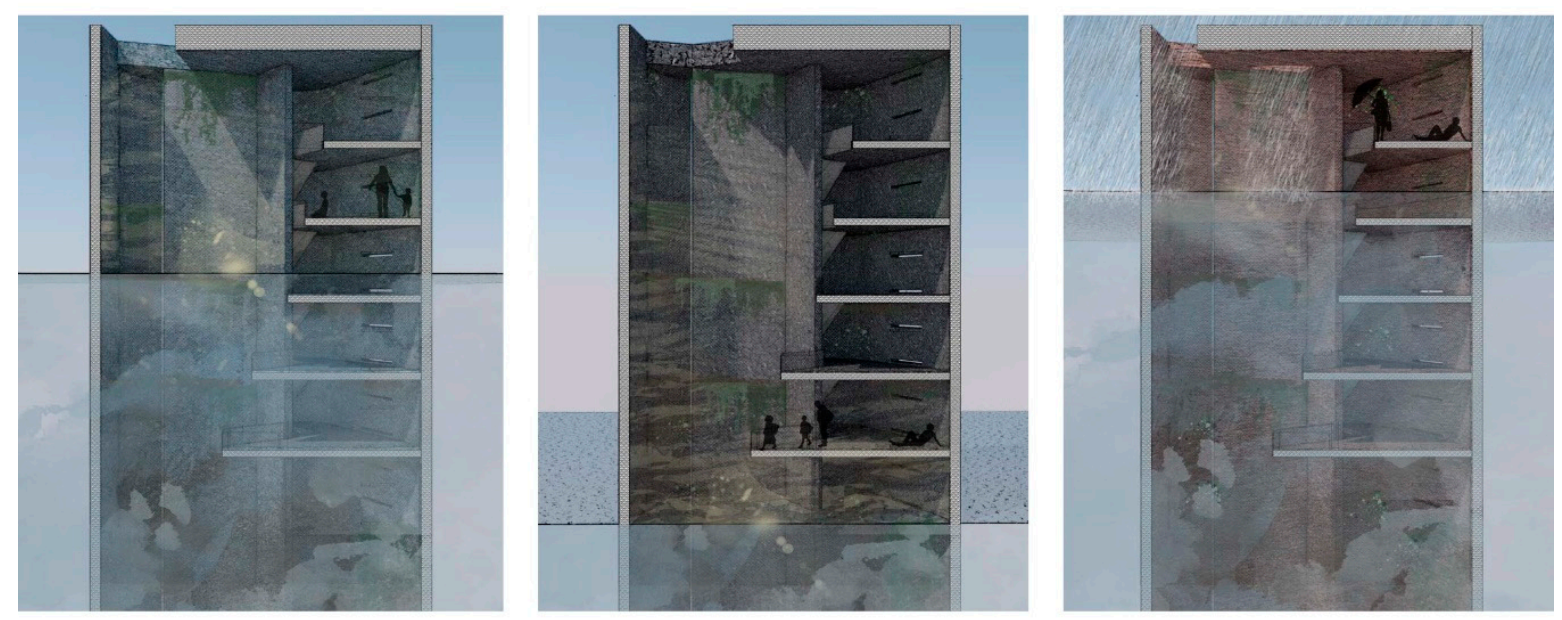

Figure 15. Varying water levels in the towers.

Cultural Services: This slow lake crossing constitutes a mindfulness experience and an entrance to the hiking trails and further nature on the west side of the lake. It will physically slow the visitors down and create awareness of the beautiful, ever-shifting landscape. The zigzag form of the route is designed to show the surroundings through different perspectives, while these towers are placed alongside a small isle where they can see the impact of the rising water level on this environment. Each tower in the water represents a season. Each tower, with its material, will blend in with the landscape during its season, underlining the constantly changing landscape (Figure 16). 

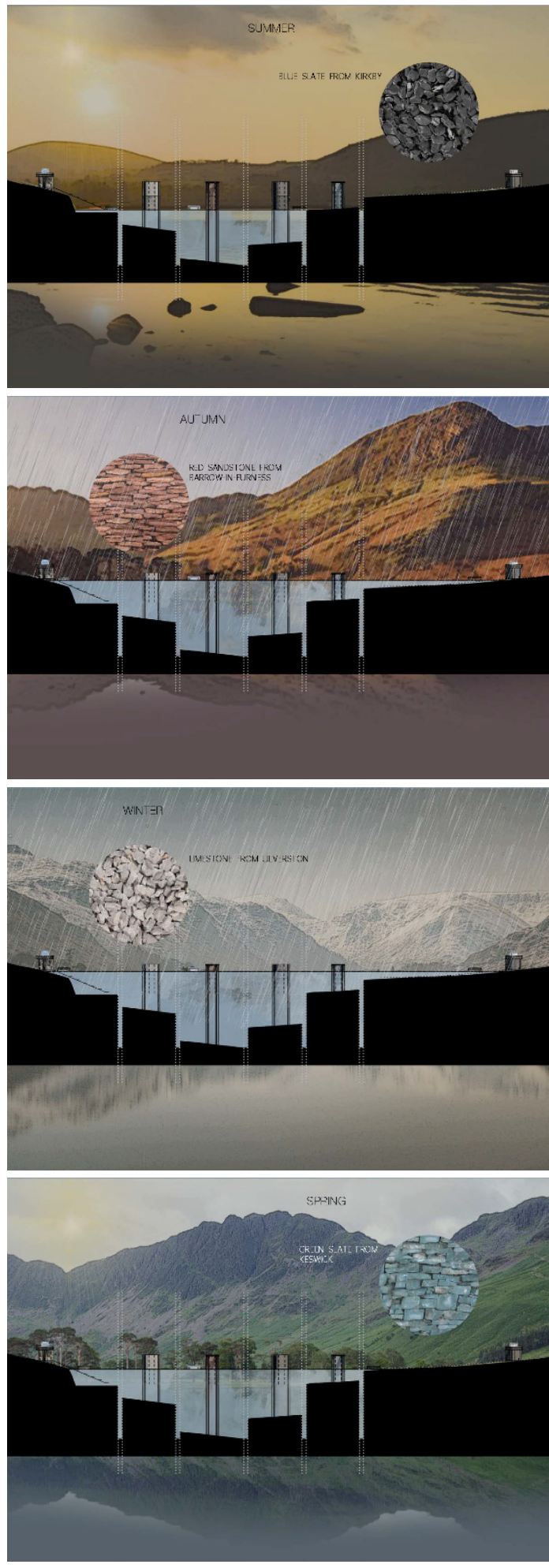

Figure 16. Seasonality and materialization of the towers.

\section{Step 4-Gradual Implementation}

The proposed idea can be implemented as the first part of a broader network of slow tourism activities in the Lake District, where water and floods play a key role. 


\subsubsection{Design Research Project 3 I Waterdefence Trail Kescale}

This design research project focuses on the area between Keswick and Portinscale and aims to connect these two towns with a walking route. Apart from promoting slow mobility, it also serves as a linear cultural space where various activities and events can be hosted, contributing to the mental and social realm of the area. Most importantly, next to the route, terraced agricultural land is developed, which can also serve as a buffer zone in case of flooding.

\section{Step 1-Past Equilibrium: Autonomy in Food Production}

The Lake District has been increasingly affected by floods and droughts, as well as soil and bank erosion. The consequences are devastating for people, property, and land. Moreover, climate-driven disasters and deforestation have gained momentum through extensive sheep farming. This results in reduced agricultural land and increased food imports.

The soil of the Lake District varies between heavy, waterlogged peat in scattered areas and freely draining sandy loam. The latter is higher in altitude and contributes to the extreme water conditions lower down. The water and nutrients drain through the sand, passing over the peat. This makes the water acidic and, eventually, this water fills up the lakes and contributes to the changing $\mathrm{pH}$ value. In combination with using the high-altitude areas for sheep grazing, the soil cannot be rehabilitated as shrub growth is restricted. Without a root system to anchor the soil and dead foliage to compost, the sand cannot develop into a more absorbent consistency, contributing to a faster rate of erosion. It took 10,000 years for the soils in the Lake District to develop, yet they are deteriorating now at a rate of $3 \mathrm{~cm}$ a year due to human interference $[62,63]$.

\section{Step 2-The Worst-Case Flooding Scenario}

The worst-case flood scenario for the area of Keswick and Portinscale is used as a basis for this proposal (Figure 17).
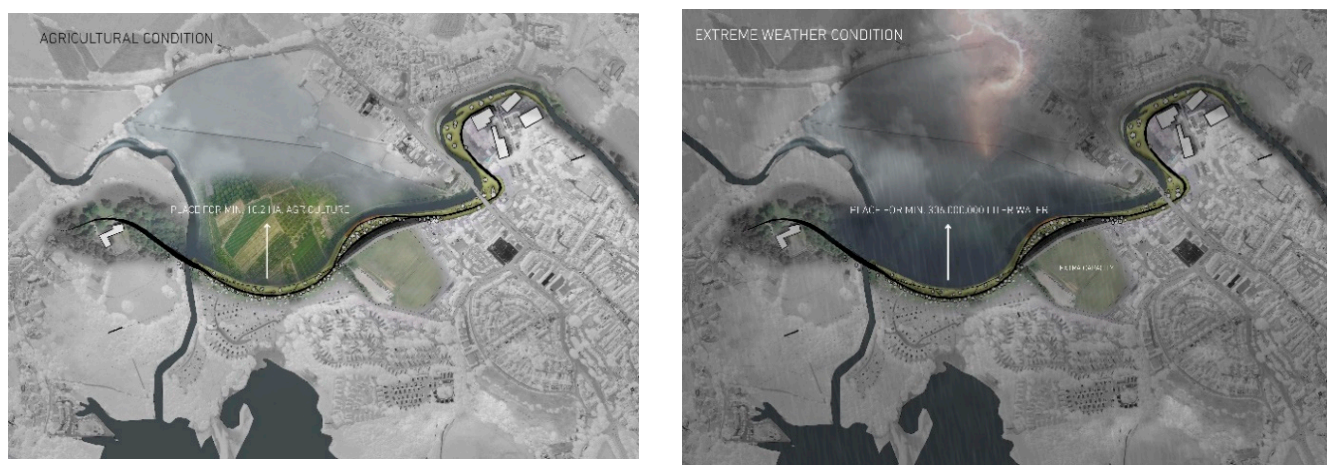

Figure 17. Agricultural land in terraces, next to the recreational route. It can receive an excessive body of water in extreme rainfall and flooding conditions.

Step 3-Safeguarding/Enhancing Ecosystem Services

Regulating Services: The design proposes a route connecting the two key towns (Keswick and Portinscale), with facilities to accommodate cultural activities (education center, adventure center, etc.). The route is next to the river Greta (Figure 18) and is expected to positively contribute to the fight against riverbank erosion.

Cultural Services: This recreational route connects people to their landscape and heritage, while providing flood defense to the towns. Tourism will be positively affected, and entertaining activities, such as biking, and canoe activities are included. Camping and open-air events adjacent areas are incorporated into this connecting route.

Provisioning and Supporting Services: Agricultural land in terraces is developed next to the recreational route. In extreme rainfall and flooding conditions, it receives an 
excessive body of water (Figure 18). It can gradually contribute to local food production and enhance biodiversity via seasonal and wet farming.

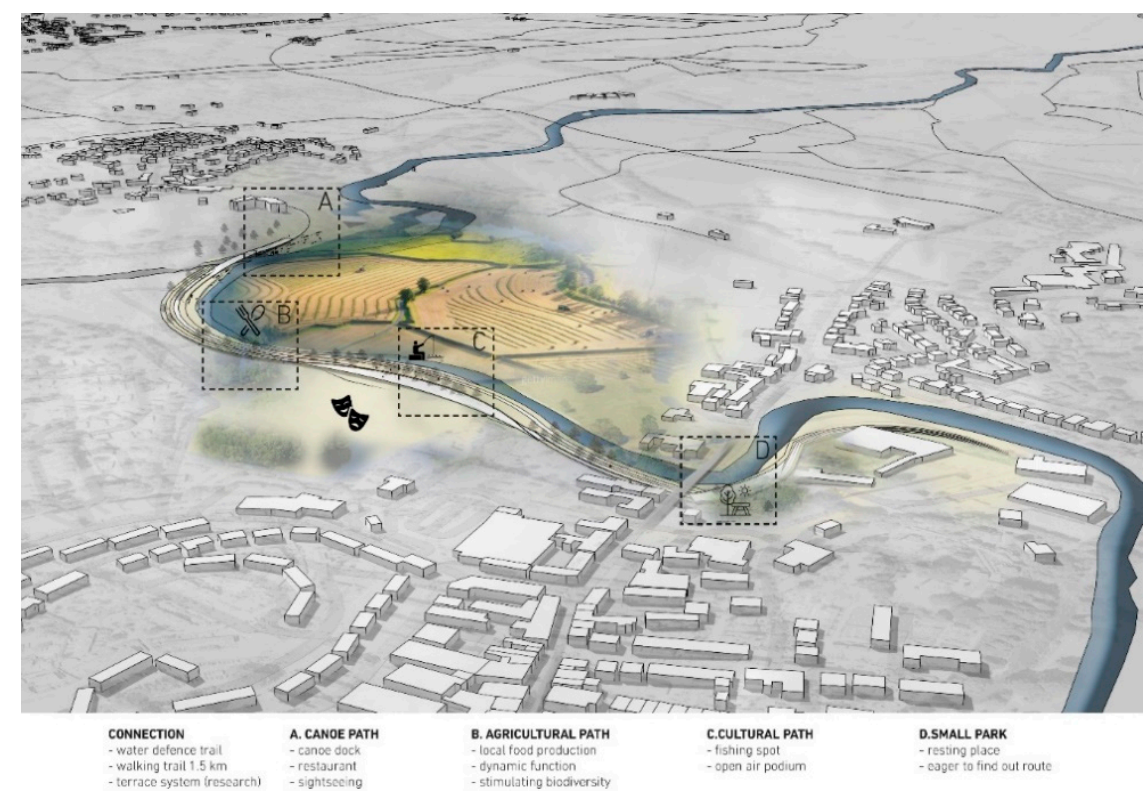

Figure 18. Masterplan of the proposed connecting route.

\section{Step 4-Gradual Implementation}

This plan is a generic solution, which can gradually develop to a landscape strategy along the course of the river over a long period of time. In this way it can extend beyond the two towns, actively contributing to the safety of the local communities.

\section{Discussion}

\subsection{Key Findings}

The purpose of this study was to propose a research by design strategy for climate adaptation solutions by using the low-density territory of the Lake District as a case study. The strategy consisted of the following steps: investigating the system equilibrium in the past, the worst-case scenario, incorporating the relevant ecosystem services in the final proposal, and gradual flexible implementation. The suggested four steps include a particular focus on the spatiotemporal dynamics of climate change, with a long-term climate adaptation planning objective. The four steps coincide with the divergence and convergence iterative phases that characterize the research by design process. Regular review and feedback sessions with peers, tutors, and stakeholders served as the platform for the iterative process. The main outcome of each step serves as an input for the next step, while it is simultaneously re-examined and reconsidered through the new perspective and direction provided by the subsequent step (the students went through iterative subsequent phases). The proposed integrated approach was developed and implemented in the context of a research and design studio at a Master of Architecture degree program in the Netherlands. Whilst the strategy helped the students to comprehend the space and time dimensions of the low-density landscape of the Lake District, UK and to design innovative climate adaptation solutions, there were issues that the students did not or could not tackle within the constraints of the studio. The shortfalls in their approaches will be discussed later within this article. The design research projects differed in terms of scale and theme: different aspects of the food system, water system and flooding, energy transition, tourism, mobility, and cultural heritage were emphasized. Within the overall educational process, the students were encouraged to formulate their research questions and individual standpoint concerning climate adaptation. This strategy enabled the effective implementation 
of research by design, gave important structure to these vertical studios, and resulted in innovative and creative climate adaptation design proposals.

Three design research projects with a particular focus on flooding were selected to illustrate the proposed research by design strategy. Interestingly, although all three cases prioritized resilience against frequent flooding, they all approached this design challenge through different perspectives, emphasizing mobility and quality of urban life, tourism and cultural identity, or recreation and food production.

The starting point of the three design research projects was to approach the study area as a system and analyze its history. The water management history and the resistance and resilience approaches [36] that took place in the study area were the focus of the first project. The second project investigated tourism and local identity. The third project studied soil conditions and food production. Juxtaposing different layers of analyses (such as different thematic aspects or different time periods, etc.) constituted an integral part of this process.

The second step in all three projects was the formulation of a worst-case scenario regarding the impact of climate change on the study area. As explained above, the three projects focused on extreme weather phenomena and, particularly, on the increased frequency and intensity of heavy rainfall and flooding. Notably, formulating the worst-case flooding scenario for the study area helps to unveil the size of the threat, to realize its spatial implications, and to convert it into an opportunity (by exploring ways of unraveling the transformative potential of the study area).

The identification of the relevant ecosystem services leads to more comprehensive proposals that take the physical and the mental sphere into account. All three projects explored, by implementing research by design, how spatial interventions can create a positive impact on the area. For instance, in the first case, the dancing street concept is mostly related to regulating ecosystem services (street design); however, the transformation of the street elements into an interactive spatial game in case of heavy rainfall relates to cultural services as well, affecting the social/cultural/identity-related sphere. In the second project, cultural services are prioritized. However, the regulation of services is also taken into account by allowing the towers to flood and thus making them more resilient. Finally, in the third case, provisioning and supporting services play a key role (with the proposed system of terrace cultivation and by deliberately giving space to excessive water, in case of flooding). However, the route connecting the two towns is also directly related to cultural services.

The gradual and flexible implementation process of the designed solution was considered in all three design research projects. Essentially, the implementation process adopts a complex adaptive system approach by embracing uncertainty and leaving space for the unpredictable. In all three projects, the upscaling potential of the proposed design solution was emphasized.

Finally, it is interesting to note that all the three design research projects concluded with proposals which ultimately aimed at a lifestyle change (of residents and visitors). In general, during the research and design studios, this helped students and teachers to realize the continued importance of the human factor in spatial systemic intervention. Considering the focus upon climate adaptation and mankind's interaction with the natural environment at different scales, it was also concluded that individuals and communities would have to adapt culturally through occasionally dramatic changes in behavior if the designed solutions to increase adaptability were to have any significant impact. Diamond [64] describes cultural adaptability as the decisive factor in a civilization's potential resilience to internal and external forces of change.

\subsection{Theoretical Contribution and Design Implications}

The main theoretical contribution of this study is the development of a four-step strategy that is aligned with the research by design approach. This strategy helped the researchers and designers to effectively approach and analyze a study area and formulate an innovative climate adaptation design proposal. 
Additionally, the proposed strategy acts as a roadmap for advances in pedagogical techniques. The strategy undertaken in the design studio also enhanced students' development as researchers by helping them to comprehend contemporary environmental and climate change challenges. Therefore, further studies on research by design methodology to investigate different low-density contexts across various scales should be encouraged.

Resembling the results of Amenta and Qu [15], the research by design method helped the students to assess the research relevancy of their design work. The exploratory nature of the process encouraged the students to tackle uncertainty and avoid design fixation. Mapping and visualization techniques played a key role in the overall process.

\subsection{Limitations and Future Research}

More practice-based studies are needed to provide concrete examples and hence to discuss the potential of the proposed four-step strategy in climate adaptation design. As discussed in the previous sub-section, the findings demonstrate context-specific data collected in a particular Master of Architecture degree program. However, the results can be generalized to other urban design studies in different spatial contexts. The studio outcomes do nonetheless raise questions concerning the thoroughness or scope of the methodology. For example, when considering the flood risk scenarios in the surroundings of Windermere, it was not possible for the students to fully envisage the environmental qualities of the previous state of equilibrium in the specific area or broader region. The design interventions are therefore arguably not complete or comprehensive but do in any case highlight new ways of understanding and intervening in the context of climate change.

Both studios started with open questions concerning climate adaptation. These questions were then transformed into more specific design problems and briefs. The students worked mostly individually on the design process. For practice-based implications of research by design, collective learning processes via charrettes and workshops can be incorporated into the design process $[10,65]$, while the proposed four-step methodology can be utilized to offer more structure in these collective efforts.

This research by design strategy and similar design-oriented approaches that focus on the sudden impacts of climate change can also be utilized to enhance the dissemination of outputs from Early Warning Systems [22,23] to reinforce the Civil Protection Mechanisms [66]. However, more research is needed to effectively evaluate the potential contribution of research by design to such early warning systems and civil protection mechanisms.

Finally, the critical and crucial role that local societies can play in the divergence and convergence phases of all the four steps of the strategy should be further analyzed and tested. For instance, local societies can significantly contribute to the research process of backcasting, to collect and juxtapose the appropriate information to unravel the full potential and the spatial diversity of an area. Thus, future work could incorporate in each of the four proposed steps a co-design and/or public consultation stage, in which proposed solutions may be co-created so that the local inhabitants' requirements and preferences are taken into account.

\section{Conclusions}

The purpose of this paper was to propose an innovative research by design strategy, embedded to the design thinking process framework and to generate out-of-the-box, creative climate adaptation solutions. The proposed four-step strategy was implemented and tested in a research and design studio, which took place in 2020 at a Master of Architecture program in the Netherlands. The studio focused on the low-density, high flood risk region of the Lake District, UK, an area facing urgent climate change challenges which demand effective solutions.

The strategy encourages the formulation of tailor-made, local solutions, which emphasize and strengthen the potential and opportunities of the study area. These local solutions serve as the pylons of the design proposal and are revealed through a spatiotemporal 
analysis of the study area, which aims at identifying the most recent point of time when the system was in equilibrium. The qualities revealed by examining that state, in combination with the formulation and illustration of the worst-case climate change scenario for the study area, provide the necessary input for the development of a climate adaptation concept. Then, considering the services relevant to the study area ecosystem allowed the analysis of the spatial-systemic and the mental sphere of the study area and the formulation of comprehensive, multi-faceted climate adaptation solutions. Formulating climate adaptation design interventions, which can be gradually implemented in the study area, and also proposing how this gradual transition can take place, was the last step of the proposed four-step strategy.

Overall, it can be concluded that the proposed strategy helps the researcher designer to embrace uncertainty and to generate long term solutions, to convert the threats of climate change into opportunities and to arrive at radical and efficient solutions which take into account of both the physical and the mental sphere of the study area. Moreover, the findings of the study also demonstrate that the students improved their understanding of climate adaptation design.

Finally, it is suggested that possible future studies focus on implementing and evaluating the proposed strategy in various spatial contexts and scales. Further development and refinement of the strategy is also suggested, which can be achieved by involving local actors in the different phases of the research by design process (co-creation processes).

Author Contributions: Conceptualization, I.P. and Ö.A.G.; methodology, I.P.; investigation, I.P. and Ö.A.G.; resources, I.P. and Ö.A.G.; data curation, I.P.; writing-original draft preparation, I.P. and Ö.A.G.; writing - review and editing, I.P., Ö.A.G. and A.v.S.; visualization, I.P.; project administration, I.P. All authors have read and agreed to the published version of the manuscript.

Funding: This research received no external funding.

Institutional Review Board Statement: Not applicable.

Informed Consent Statement: Not applicable.

Acknowledgments: The writers feel the need to acknowledge with gratitude the following important contributions to this study. First, the rest of the teaching team members of these two studios (which took place in 2020, at the Academy of Architecture, Hanze University Groningen): the architects Myriam Lopez Rodero, Loes Oudenaarde and Boris Bahre. Second, the students participating in these two studios and formulating an active learning community, with special reference to Esther Postma, Rachel Tillotson, Jordy Vijfschaft, Yasmin Veenstra, Martin Groen (group work for Figure 3); Theo Brouwer, Victor Bruinen, Annelies Faber, Julia Frohlich, Davey de Nekker (group work for Figure 4), and especially to Anne Taeke Meijer (Figures 4-11), Nienke Veenhuis (Figures 4 and 12-16) and Jacob Krol (Figures 3, 17 and 18), whose research design projects were selected to be described and discussed in this paper. Third, the significant contribution of Rob Roggema in setting up the two studios is acknowledged and highly appreciated. We are grateful for the significant contribution of the students and especially the teachers of the Queen's University Belfast Greg Keeffe and Sean Cullen in setting up the Research and Design studios and the exchange of valuable information concerning the study area [67]. We also thank all the people who gave lectures during the Research and Design Studios in the Academy of Architecture, Hanze University Groningen. Last but not least, special thanks is given to the architect and researcher Clemens Bernardt for his critical comments and in-sights in this study.

Conflicts of Interest: The authors declare no conflict of interest.

\section{References}

1. Adger, V.N. Social Capital, Collective Action, and Adaptation to Climate Change. Econ. Geogr. 2003, 79, 387-404. [CrossRef]

2. Biesbroek, G.R.; Swart, R.J.; van der Knaap, W.G.M. The Mitigation-Adaptation Dichotomy and the Role of Spatial Planning. Habitat Int. 2009, 33, 230-237. [CrossRef]

3. Bosello, F.; Carraro, C.; De Cian, E. Climate Policy and the Optimal Balance between Mitigation, Adaptation and Unavoided Damage. Clim. Chang. Econ. 2010, 1, 71-92. [CrossRef] 
4. Lee, T.; Yang, H.; Blok, A. Does Mitigation Shape Adaptation? The Urban Climate Mitigation-Adaptation Nexus. Clim. Policy 2020, 20, 341-353. [CrossRef]

5. Dhar, T.K.; Khirfan, L. Climate Change Adaptation in the Urban Planning and Design Research: Missing Links and Research Agenda. J. Environ. Plan. Manag. 2017, 60, 602-627. [CrossRef]

6. Rittel, H.W.J.; Webber, M.M. Dilemmas in a General Theory of Planning. Policy Sci. 1973, 4, 155-169. [CrossRef]

7. Davoudi, S.; Crawford, J.; Mehmood, A. Planning for Climate Change: Strategies for Mitigation and Adaptation for Spatial Planners; Earthscan: London, UK, 2009; ISBN 978-1-84977-015-6.

8. Roggema, R.; Vermeend, T.; Dobbelsteen, A.V. den Incremental Change, Transition or Transformation? Optimising Change Pathways for Climate Adaptation in Spatial Planning. Sustainability 2012, 4, 2525-2549. [CrossRef]

9. Roggema, R. The Future of Sustainable Urbanism: Society-Based, Complexity-Led, and Landscape-Driven. Sustainability 2017, 9 , 1442. [CrossRef]

10. Vanin, F.; De Visscher, J.-P.; Mezoued, A.; Vermeulen, S. A Common Vision for the Brussels Metropolitan City Centre beyond the Pentagon. In Towards a Metropolitan City Centre for Brussels; EUB VUBPress: Brussels, Belgium, 2020; pp. 243-274.

11. Cattaneo, T.; Giorgi, E.; Ni, M. Landscape, Architecture and Environmental Regeneration: A Research by Design Approach for Inclusive Tourism in a Rural Village in China. Sustainability 2019, 11, 128. [CrossRef]

12. Charoenlertthanakit, N.; Wanitchayapaisit, C.; Yaipimol, E.; Surinseng, V.; Suppakittpaisarn, P. Landscape Planning for an Agricultural Research Center: A Research-by-Design Case Study in Chiang Mai, Thailand. Land 2020, 9, 149. [CrossRef]

13. Roggema, R. Research by Design: Proposition for a Methodological Approach. Urban Sci. 2017, 1, 2. [CrossRef]

14. van den Boomen, T.; Frijters, E.; van Assen, S.; Broekman, M. Urban Challenges, Resilient Solutions: Design Thinking for the Future of Urban Regions; TrancityxValiz: Haarlem, The Netherlands, 2017; ISBN 978-94-92095-33-6.

15. Amenta, L.; Qu, L. Experimenting with Circularity When Designing Contemporary Regions: Adaptation Strategies for More Resilient and Regenerative Metropolitan Areas of Amsterdam and Naples Developed in University Studio Settings. Sustainability 2020, 12, 4549. [CrossRef]

16. Dubois, C.; Cloutier, G.; Potvin, A.; Adolphe, L.; Joerin, F. Design Support Tools to Sustain Climate Change Adaptation at the Local Level: A Review and Reflection on Their Suitability. Front. Archit. Res. 2015, 4, 1-11. [CrossRef]

17. Lenzholzer, S.; Brown, R.D. Climate-Responsive Landscape Architecture Design Education. J. Clean. Prod. 2013, 61, 89-99. [CrossRef]

18. Levin, S.; Xepapadeas, T.; Crépin, A.-S.; Norberg, J.; de Zeeuw, A.; Folke, C.; Hughes, T.; Arrow, K.; Barrett, S.; Daily, G.; et al. Social-Ecological Systems as Complex Adaptive Systems: Modeling and Policy Implications. Environ. Dev. Econ. 2013, 18, 111-132. [CrossRef]

19. Costanza, R.; de Groot, R.; Braat, L.; Kubiszewski, I.; Fioramonti, L.; Sutton, P.; Farber, S.; Grasso, M. Twenty Years of Ecosystem Services: How Far Have We Come and How Far Do We Still Need to Go? Ecosyst. Serv. 2017, 28, 1-16. [CrossRef]

20. Young, D.; Essex, S. Climate Change Adaptation in the Planning of England's Coastal Urban Areas: Priorities, Barriers and Future Prospects. J. Environ. Plan. Manag. 2020, 63, 912-934. [CrossRef]

21. Restemeyer, B. Planning for Flood Resilient Cities: From Promise to Practice? Thesis Fully Internal (DIV). Ph.D. Thesis, University of Groningen, Groningen, The Netherlands, May 2018.

22. Kelman, I.; Glantz, M.H. Early Warning Systems Defined. In Reducing Disaster: Early Warning Systems for Climate Change; Singh, A., Zommers, Z., Eds.; Springer: Dordrecht, The Netherlands, 2014; pp. 89-108, ISBN 978-94-017-8598-3.

23. De Luca, D.L.; Versace, P. Diversity of Rainfall Thresholds for Early Warning of Hydro-Geological Disasters. Adv. Geosci. 2017, 44, 53-60. [CrossRef]

24. Yan, W.; Roggema, R. Developing a Design-Led Approach for the Food-Energy-Water Nexus in Cities. Urban Plan. 2019, 4, 123-138. [CrossRef]

25. Salet, W.; Bertolini, L.; Giezen, M. Complexity and Uncertainty: Problem or Asset in Decision Making of Mega Infrastructure Projects? Int. J. Urban Reg. Res. 2013, 37, 1984-2000. [CrossRef]

26. Helmrich, A.M.; Chester, M.V. Reconciling Complexity and Deep Uncertainty in Infrastructure Design for Climate Adaptation. Sustain. Resil. Infrastruct. 2020, 1-17. [CrossRef]

27. Hallegatte, S. Strategies to Adapt to an Uncertain Climate Change. Glob. Environ. Change 2009, 19, 240-247. [CrossRef]

28. Roggema, R.; Genel, Ö.; Psarra, I. Toukomst of Groningen: Linking public with policy. In Spatial Transformations 2020: Applied Research for the ReciproCity; Hanze University of Applied Sciences, Groningen-Research Centre for Built Environment: Groningen, The Netherlands, 2020; pp. 14-58.

29. Brenner, N. The Hinterland Urbanised? Archit. Des. 2016, 86, 118-127. [CrossRef]

30. Domon, G. Landscape as Resource: Consequences, Challenges and Opportunities for Rural Development. Landsc. Urban Plan. 2011, 100, 338-340. [CrossRef]

31. Pinto-Correia, T.; Primdahl, J.; Pedroli, B. European Landscapes in Transition: Implications for Policy and Practice; Cambridge Studies in Landscape Ecology; Cambridge University Press: Cambridge, UK, 2018; ISBN 978-1-107-07069-1.

32. Pedroli, B.; Pinto Correia, T.; Primdahl, J. Challenges for a Shared European Countryside of Uncertain Future. Towards a Modern Community-Based Landscape Perspective. Landsc. Res. 2016, 41, 450-460. [CrossRef]

33. Brand, N.; Kersten, I.; Pot, R.; Warmerdam, M. Research by Design on the Dutch Coastline: Bridging Flood Control and Spatial Quality. Built Environ. 2014, 40, 265-280. [CrossRef] 
34. Genel, Ö.A.; Guan, C. Assessing Urbanization Dynamics in Turkey's Marmara Region Using CORINE Data between 2006 and 2018. Remote Sens. 2021, 13, 664. [CrossRef]

35. Almeida Ramos, G.M.; de Fernandes, J.L.J. Tourism Territories in Low Density Areas: The Case of Naturtejo Geopark in Portugal. J. Tour. Herit. Serv. Mark. 2016, 2, 14-21. [CrossRef]

36. Restemeyer, B.; Woltjer, J.; van den Brink, M. A Strategy-Based Framework for Assessing the Flood Resilience of Cities-A Hamburg Case Study. Plan. Theory Pract. 2015, 16, 45-62. [CrossRef]

37. Wordsworth, W. A Guide Through the District of the Lakes in the North of England: With A Description of the Scenery, Ec. For the Use of Tourists and Residents; Franklin Classics: Franklin, MA, USA, 2018; ISBN 978-0-343-20517-1.

38. Neilson, A. Disenchanted Natures: A Critical Analysis of the Contested Plan to Reintroduce the Eurasian Lynx into the Lake District National Park. Capital. Nat. Soc. 2021, 32, 107-125. [CrossRef]

39. Hope, D. The Democratisation of Tourism in the English Lake District: The Role of the Co-Operative Holidays Association and the Holiday Fellowship. J. Tour. Hist. 2016, 8, 105-126. [CrossRef]

40. de Queiroz Barbosa, E.R.; DeMeulder, B.; Gerrits, Y. Design Studio as a Process of Inquiry: The Case of Studio Sao Paulo. Lusofona J. Archit. Educ. 2014, 11, 241-254.

41. Van de Weijer, M.; Van Cleempoel, K.; Heynen, H. Positioning Research and Design in Academia and Practice: A Contribution to a Continuing Debate. Des. Issues 2014, 30, 17-29. [CrossRef]

42. Schon, D.A. Reflective Practitioner: How Professionals Think in Action; Basic Books: New York, NY, USA, 1984; ISBN 978-0-465-06878-4.

43. Hauberg, J. Research by Design-Situating Practice-Based Research as Part of a Tradition of Knowledge Production, Exemplified through the Works of Le Corbusier. Lusofona J. Archit. Educ. 2014, 11, 57-76.

44. Ramsgaard Thomsen, M.; Tamke, M. Narratives of Making: Thinking Practice Led Research In Architecture. In Proceedings of the Conference Communicating (by)Design, Bruxelles, Belgium, 15-17 April 2009; pp. 1-8.

45. Redström, J. Certain Uncertainties and the Design of Design Education. She Ji J. Des. Econ. Innov. 2020, 6, 83-100. [CrossRef]

46. Grimm, V.; Wissel, C. Babel, or the Ecological Stability Discussions: An Inventory and Analysis of Terminology and a Guide for Avoiding Confusion. Oecologia 1997, 109, 323-334. [CrossRef] [PubMed]

47. Beyond Connecting the Dots. Available online: http:/ / beyondconnectingthedots.com/ (accessed on 16 October 2021).

48. Wilson, E.; Piper, J. Spatial Planning and Climate Change; Routledge: London, UK, 2010; ISBN 978-0-203-84653-7.

49. Porter, M.G.; de Roo, P.G. Fuzzy Planning: The Role of Actors in a Fuzzy Governance Environment; Ashgate Publishing, Ltd.: Aldershot, UK, 2012; ISBN 978-1-4094-8739-5.

50. Roggema, R. Dutch and Australian Planning Regimes: Are They Ready to Face Extreme Climate Impacts? Eur. Plan. Stud. 2014, 22, 2067-2093. [CrossRef]

51. Picchi, P.; van Lierop, M.; Geneletti, D.; Stremke, S. Advancing the Relationship between Renewable Energy and Ecosystem Services for Landscape Planning and Design: A Literature Review. Ecosyst. Serv. 2019, 35, 241-259. [CrossRef]

52. Stremke, S.; Picchi, P. Co-Designing Energy Landscapes: Application of Participatory Mapping and Geographic Information Systems in the Exploration of Low Carbon Futures. In Handbook on the Geographies of Energy; Edward Elgar Publishing: Cheltenham, UK, 2017; pp. 368-379, ISBN 9781785365621.

53. Smets, M.; Shannon, K. The Landscape of Contemporary Infrastructure; NAi Publishers: Rotterdam, The Netherlands, 2016; ISBN 978-94-6208-239-7.

54. Avermaete, T.; Havik, K.; Teerds, P. Architectural Positions. Architecture, Modernity and the Public Sphere; SUN Publishers: Nijmegen, The Netherlands, 2009; ISBN 978-90-8506-566-1.

55. M.E.A. Millennium Ecosystem Assessment. Available online: http://www.millenniumassessment.org/en/Synthesis.html (accessed on 15 October 2021).

56. Millennium Ecosystem Assessment. Ecosystems and Human Well-Being: Synthesis; Island Press: Washington, DC, USA, 2005.

57. Wandl, A.; Balz, V.; Qu, L.; Furlan, C.; Arciniegas, G.; Hackauf, U. The Circular Economy Concept in Design Education: Enhancing Understanding and Innovation by Means of Situated Learning. Urban Plan. 2019, 4, 63-75. [CrossRef]

58. Climate Change. Available online: https://www.lakedistrict.gov.uk/learning/weatherandclimate/factsclimatechange (accessed on 15 October 2021).

59. Hoskins, W.G.; Boyd, W. The Making of the English Landscape; Little Toller Books: Toller Fratrum, Dorset, UK, 2013; ISBN 978-1-908213-10-5.

60. Wilson, E. Adapting to Climate Change at the Local Level: The Spatial Planning Response. Local Environ. 2006, 11, 609-625. [CrossRef]

61. Check the Long Term Flood Risk for an Area in England. Available online: https://www.gov.uk/check-long-term-flood-risk (accessed on 15 October 2021).

62. Townend, I.; Sayers, P.B.; Hinton, C.; Panzeri, M.C.; Cooper, N.; Nicholls, R.J.; Thorne, C.R.; Simm, J. OST Foresight Report: A Futures Analysis of UK Coastal Flooding and Erosion. In International Conference on Coastlines, Structures and Breakwaters 2005; Thomas Telford Publishing: London, UK, 2005; pp. 1-18, ISBN 978-0-7277-4625-2.

63. Evans, E.P.; Simm, J.D.; Thorne, C.R.; Arnell, N.W.; Ashley, R.M.; Hess, T.M.; Lane, S.N.; Morris, J.; Nicholls, R.J.; Penning-Rowsell, E.C.; et al. An Update of the Foresight Future Flooding 2004 Qualitative Risk Analysis; Cabinet Office: London, UK, 2008. 
64. Diamond, J. Collapse: How Societies Choose to Fail or Succeed: Revised Edition; Viking Press: New York, NY, USA, 2011; ISBN 978-0-14-311700-1.

65. Roggema, R. The Design Charrette. In The Design Charrette: Ways to Envision Sustainable Futures; Roggema, R., Ed.; Springer: Dordrecht, The Netherlands, 2014; pp. 15-34, ISBN 978-94-007-7031-7.

66. Hans EU Civil Protection Mechanism. Available online: https://ec.europa.eu/echo/what/civil-protection/mechanism_en (accessed on 16 October 2021).

67. Cullen, S.; Keeffe, G. Neitherland: Mutability and Low-Density Landscapes; McGowans: Belfast, UK, 2020; ISBN 978-1-909731-90-5. 